\title{
Some Observations on the Microsomal Electron Transport System and Activities of Drug Oxidizing Enzymes in Human Liver
}

\author{
Tetsuya Kamataki, Mitsukazu Kitada, and Haruo Kitagawa \\ Department of Biochemical Pharmacology, Faculty of Pharmaceutical \\ Sciences, University of Chiba ${ }^{1)}$
}

(Received January 14, 1972)

\begin{abstract}
1. Aniline-induced difference spectrum in post-mortem human liver microsomes was recognized as type II similar to that in rat liver. Hexobarbital- and aminopyrineinduced P-450 difference spectra were also of type II in human, but they were different from those in rat liver microsomes.

2. There was no correlation between enzyme activities of the NADPH-linked electron transport system in liver microsomes and aniline hydroxylase activity in human liver, which was similar to that of rat liver. The activity of hydroxylation of hexobarbital, a type I compound, in human was lower than that in rat liver, and a similar result was observed when aminopyrine was used as substrate.
\end{abstract}

\section{Introduction}

There are some reports on the activities of drug metabolizing enzymes in human liver. Coccia and Westerfeld ${ }^{2}$ studied the metabolism of chlorpromazine using $12-18 \mathrm{hr}$ postmortem human livers and Kuntzman, et al. ${ }^{3)}$ reported the metabolism of pentobarbital, acetophenetidin and 3,4-benzpyrene using the homogenates of the biopsy samples. Creaven and Williams ${ }^{4)}$ demonstrated the existence of aromatic hydroxylating activity in $4-28 \mathrm{hr}$ postmortem human livers and Ackermann and Heinrich, ${ }^{5)}$ and Ackermann ${ }^{6)}$ studied the activity of $\mathrm{N}$-methyl-p-nitroaniline $\mathrm{N}$-demethylase and the activity of $p$-nitroanisol $\mathrm{O}$-demethylase in human liver. Darby, et al. ${ }^{7)}$ investigated the metabolism of codeine, hexobarbital and aniline using post-mortem human liver microsomal preparations in vitro, and measured NADPH-cytochrome $c$ reductase activity and cytochrome $\mathrm{P}-450$ content which was previously detected by Alvares, et al. . $^{\text {) }}$ Although the properties of cytochrome P-450 have been investigated in experimental animals, little is known of its properties in human. Recently, it was shown that cytochrome P-450 in human liver $^{8)}$ and human placenta ${ }^{9)}$ had spectral characteristics similar to those already reported in animals. It is well recognized that substratecytochrome P-450 binding difference spectra induced by addition of various substrates to suspensions of liver microsomes, can be classified into two or three groups, ${ }^{10,11)}$ that is, substrates such as hexobarbital and aminopyrine, give type I difference spectrum and substrates such as aniline, give type II difference spectrum in rat liver microsomes. Yaffe,

1) Location: 1-33, Yayoicho, Chiba.

2) P.F. Coccia and W.W. Westerfeld, J. Pharmacol. Exptl. Therap., 157, 446 (1967).

3) R. Kuntzman, L.C. Mark, L. Brand, M. Jacobson, W. Levin, and A.H. Conney, J. Pharmacol. Exptl. Therap., 152, 151 (1966).

4) P.J. Creaven and R.T. Williams, Biochem. J., 87, 19 (1963).

5) E. Ackermann and I. Heinrich, Biochem. Pharmacol., 19, 327 (1969).

6) E. Ackermann, Biochem. Pharmacol., 19, 1955 (1969).

7) F.J. Darby, W. Newnes, and D.A. Price. Evans, Biochem. Pharmacol., 19, 1514 (1969).

8) A.P. Alvares, G. Schilling, W. Levin, R. Kuntzman, L. Brand, and L.C. Mark, Clin. Pharmacol. Therap., 10, 655 (1969).

9) R.A. Meigs and K.J. Ryan, Biochim. Biophys. Acta, 165, 476 (1968).

10) Y. Imai and R. Sato, Biochem. Biophys. Res. Commun., 22, 620 (1966).

11) J.R. Schenkman, H. Remmer, and R.IV. Estabrook, Mol. Pharmacol., 3, 113 (1967). 
et al. ${ }^{12)}$ demonstrated that testosterone and laurate gave type I, whereas, aminopyrine induced type II difference spectrum in fetal human liver microsomes. The present study was initiated to classify the spectral properties of cytochrome P-450 in human liver microsomes and to compare the activities of NADPH-dependent microsomal enzymes in human liver with those in rats.

\section{Method and Material}

Animals_- Male rats of Wistar strain were divided into two groups, animals of the first group weighing 100 to $125 \mathrm{~g}$ were used for measurement of drug metabolizing activity, and another weighing 400 to $430 \mathrm{~g}$ were used to study NADPH-linked electron transport system in liver microsomes.

Preparation of Rat Liver Microsomal Fraction_- Rats were fasted for $18 \mathrm{hr}$ and killed by decapitation. Livers were immediately removed and homogenized with 2 volumes of ice-cold $1.15 \% \mathrm{KCl}$ solution in a glass homogerrizer with a Teflon pestle. The homogenate was centrifuged at $9000 \times \boldsymbol{g}$ for 20 minutes, and the supernatant was recentrifuged at $105000 \times g$ for 60 minutes in a HITACHI Ultracentrifuge, Model 55-P. The pellet thus obtained was used as the microsomal fraction. The $9000 \times \boldsymbol{g}$ supernatant fraction was used as the enzyme source for measurement of durg metabolizing enzyme activities. All further procedures for the preparation of the microsomes were carried out at $0-4^{\circ}$.

Preparation of Human Liver Microsomal Fraction-Livers which were excised in judicial or administrative dissections of individuals without any histrory of drug poinsoing or liver diseases, were used. The liver samples were packed on ice and immediately handed over to us and used within $12-30 \mathrm{hr}$ after death. They were sliced and washed more than three times with ice-cold $1.15 \% \mathrm{KCl}$ solution to remove blood. Subsequent procedures were carried out as described for the case of rat liver.

Preparation of Incubation Mixture- - The incubation mixture consisted of $1 \mathrm{ml}$ of $9000 \times g$ supernatant fraction, $0.1 \mathrm{ml}$ of $\mathrm{NADP}(0.4 \mu$ mole $), 0.1 \mathrm{ml}$ of glucose-6-phosphate $(20 \mu \mathrm{mole}), 0.1 \mathrm{ml}$ of $\mathrm{MgCl}_{2}(18.75$ $\mu$ mole), $1.0 \mathrm{ml}$ of $0.2 \mathrm{M}$ phosphate buffer, $\mathrm{pH} 7.4$ and $0.2 \mathrm{ml}$ of various substrate (hexobarbital and aminopyrine, $1 \mathrm{~mm}$; aniline, $3.2 \mathrm{~mm}$ ) in a final volume of $2.5 \mathrm{ml}$. Incubation was carried out at $37^{\circ}$ with shaking.

Chemical Assays- The formation of $p$-aminophenol from aniline was determined by the method of Brodie and Axelrod ${ }^{13)}$ as modified by Kato and Gillitte. ${ }^{14)}$ Formaldehyde formation was determined by the method of Nash. ${ }^{15)} \quad$ Hydroxylase activity of hexobarbital was estimated according to the method of Cooper and Brodie. ${ }^{16)}$ Cytochrome P-450 was assayed essentially by the method of Omura and Sato ${ }^{17}$ ) using either a HITACHI recording spectrophotometer, Model EPS-3T with an integrating sphare accessory or a HITACHI two wavelength spectrophotometer, Model 356 with a constant temperature compartment. An extinction coefficient increment of $91 \mathrm{~mm}^{-1} \mathrm{~cm}^{-1}$ was used for calculation of cytochrome P-450 content from the absorbance difference between 450 and $490 \mathrm{~m} \mu$. Enzyme activities of NADPH-linked electron transport system were measured at $25^{\circ}$ by the method of Williams and Kamin ${ }^{18}$ ) using the HITACHI two wavelength recording spectrophotometer. The microsomal protein and the amount of hemoglobin were deternined according to the method of Lowry, et al. ${ }^{19)}$ and Darbkin and Austin, ${ }^{20)}$ respectively.

\section{Result and Discussion}

As shown in Fig. 1, the aniline-induced difference spectrum of cytochrome P-450 in postmortem human liver microsomes seemed to belong to type II and this was similar to that obtained in rat liver microsomes. However, the hexobarbital-induced difference spectrum seemed to belong to type II in human liver microsomes (Fig. 2), and this was different from that obtained in rat liver microsomes. The type II difference spectrum induced by hexobarbital had an absorption peak at about $412 \mathrm{~m} \mu$ and a trough at about $380 \mathrm{~m} \mu$. It is very interesting that the type II difference spectrum induced by hexobarbital in human had a peak at shorter wave length than the type II difference spectrum induced by type II com-

12) S.J. Yaffe, A. Rane, F. Sjöqvist, L.-O. Boréus, and S. Orrenius, Life Sciences, 9, 1189 (1970).

13) B.B. Brodie and J. Axelrod, J. Pharmacol. Exptl. Therap., 94, 22 (1948).

14) R. Kato and J.R. Gillette, J. Pharmacol. Exptl. Therap., 150, 279 (1965).

15) T. Nash, Biochem. J., 55, 416 (1953).

16) J.R. Cooper and B.B. Brodie, J. Pharmacol. Exptl. Therap., 114, 409 (1955).

17) T. Omura and R. Sato, J. Biol. Chem., 239, 2370 (1964).

18) C.H. Williams and H. Kamin, J. Biol. Chem., 237, 587 (1962).

19) O.H. Lowry, N.J. Rosebrough, A.L. Farr, and R.J. Randall, J. Biol. Chem., 193, 265 (1951).

20) D.L. Darbkin and J.H. Austin, J. Biol. Chem., 112, 89 (1935-1936). 


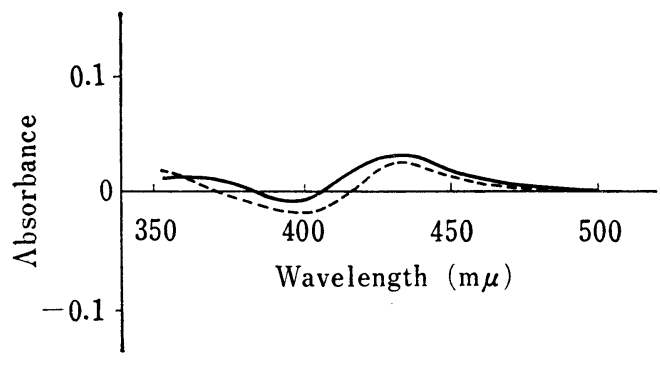

Fig. 1. Aniline Difference Spectrum with Microsomes from Human Liver

(Protein concentration, $2.97 \mathrm{mg} / \mathrm{ml}$; P-450 content, 0.136 m $\mu$ mole/mg prot.) ---: $2.67 \mathrm{~mm}$ aniline, $-: 6.67 \mathrm{~mm}$ aniline The liver used was taken from a man who was 34 years old at death.

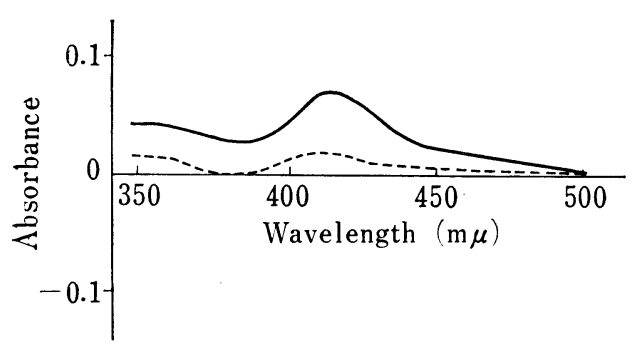

Fig. 3. Aminopyrine Difference Spectrum with Microsomes from Human Liver

(protein concentration, $2.69 \mathrm{mg} / \mathrm{ml}$; $\mathrm{P}-450$ content, $0.137 \mathrm{~m} \mu \mathrm{mole} / \mathrm{mg}$ prot.)

----: $1.0 \mathrm{~mm}$ aminopyrine, $-: 5.0 \mathrm{~mm}$ aminopyrine The liver used was the same as in Fig. 2.

by aging of livers or not. The spectral change per mis spectra in human liver were caused by aging of livers or not. The spectral change per microsomal protein was decreased with increasing time after death but the difference spectrum was not changed from type I to type II. A possible interaction with hemoglobin was examined using a standard sample of human hemoglobin at a concentration of $0.05 \mathrm{mg} / \mathrm{ml}$ which was equivalent to the content of hemoglobin remaining in these liver microsomal fractions. Hemoglobin did not show any similar difference spectra when hexobarbital and aminopyrine were used as the substrates. Therefore, the type II difference spectra in human liver microsomes induced by hexobarbital and aminopyrine seemed to be caused by cytochrome P-450, but not by hemoglobin. In addition, several other possibilities were considered to account for the absence of type I spectral change in human liver microsomes. The first is that the instability of type I binding site results in showing type II spectral change in human liver microsomes because of preservation for a long time. The second is that cytochrome P-450 present in adult human liver microsomal fraction may contain little or no type I binding site. The third is that affinity of substrates to type I binding site in human liver microsomal fraction is lower compared to that in rat liver microsomal fraction. Futher experiments are needed to decide which of these possibilities is the case.

As clearly recoginized from Table I, aniline hydroxylase activity of post-mortem human liver was similar to that in rats. However, the activity of hexobarbital hydroxylase in postmortem human liver was much lower than that in rats and there was a significant difference in aminopyrine demethylase activity between human and rat. In human liver, the activites 
TABle I. Comparative Study of Hepatic Microsomal Drug Metabolizing Enzymes between Human and Rats

\begin{tabular}{|c|c|c|c|c|}
\hline \multirow{2}{*}{ Measurement } & \multicolumn{3}{|c|}{ Human } & \multirow{2}{*}{$\left.\operatorname{Rat}^{a}\right)$} \\
\hline & 37.0 old of & 38 old $\hat{o}$ & Mean & \\
\hline Hydroxylation of aniline $\left.e^{b}\right)$ & 26.6 & 25.4 & 26.0 & $24.0^{c)}$ \\
\hline Hydroxylation of hexobaribital ${ }^{d}$ ) & 71.6 & 37.4 & 54.5 & 76.8 \\
\hline N-Demethylation of aminopyrine $e^{b)}$ & 6.0 & 10.9 & 8.5 & 55.8 \\
\hline
\end{tabular}

a) Rats weighing 100 to $125 \mathrm{~g}$ were used. b) $\mathrm{m} \mu \mathrm{mole} / \mathrm{mg}$ protein $/ 30 \mathrm{~min}$

c) mean value of two experiments $\quad$ d) $\mathrm{m} \mu \mathrm{mole} / \mathrm{mg}$ protein $/ 60 \mathrm{~min}$

to metabolize hexobarbital and aminopyrine which showed type II difference spectrum, were evidently lower than those of rat liver, and differences in spectral change reflected those of metabolic activities between human and rat. Activities of NADPH- oxidase and NADPHcytochrome $c$ reductase in human liver microsomes have been investigated.5,7,12) It was shown that NADPH-cytochrome $c$ reductase activity of human liver microsome was lower than that of rat liver. ${ }^{5)}$

TABLE II. Enzyme Activities of Microsomal NADPH-Linked Electron Transport System, Aniline Hydroxylation and Content of Cytochrome P-450 in Human Liver

\begin{tabular}{|c|c|c|c|c|c|c|}
\hline \multirow{2}{*}{ Measurement } & \multicolumn{4}{|c|}{ Human } & \multirow{2}{*}{\multicolumn{2}{|c|}{$\left.\operatorname{Rat}^{a}\right)$}} \\
\hline & 4 old $\hat{o}$ & 44 old $\hat{o}$ & 21 old $\hat{o}$ & Mean & & \\
\hline $\begin{array}{l}\text { NADPH-cytochrome } c \text { reductase } \\
\text { (unit/min/mg prot. } \times 10^{3} \text { ) }\end{array}$ & 9.8 & 70.8 & 178.0 & 64.96 & 113.0 & $\pm 2.0^{b)}$ \\
\hline $\begin{array}{l}\text { NADPH-2,6-DI } c) \text { diaphorase } \\
(\mathrm{m} \mu \text { moles } / \mathrm{min} / \mathrm{mg} \text { prot. })\end{array}$ & 0.7 & 59.0 & 9.8 & 23.2 & 14.5 & \pm 0.3 \\
\hline $\begin{array}{l}\text { NADPH-ferricyanide redutase } \\
\text { (m } \mu \text { moles } / \mathrm{min} / \mathrm{mg} \text { prot.) }\end{array}$ & 1.8 & 5.9 & 15.2 & 7.6 & 18.2 & \pm 1.4 \\
\hline $\begin{array}{l}\text { NADPH-oxidase } \\
\left(\mathrm{OD}_{340} \mathrm{~m} \mu / \mathrm{min} / \mathrm{mg} \text { prot. } \times 10^{3}\right)\end{array}$ & 5.1 & 3.3 & 1.7 & 3.4 & 6.7 & \pm 1.0 \\
\hline $\begin{array}{l}\text { NADPH-NT } \\
\text { (unit } / \mathrm{min} / \mathrm{mg} \text { prot. } \times 10^{3} \text { ) }\end{array}$ & 2.1 & 7.2 & 2.9 & 4.1 & 6.4 & \pm 1.0 \\
\hline $\begin{array}{l}\text { Content of cytochrome P- } 450 \\
\text { (m } \mu \text { moles/mg prot.) }\end{array}$ & 0.067 & 0.776 & 0.135 & 0.327 & 0.75 & \pm 0.021 \\
\hline $\begin{array}{l}\text { Hydroxylation of aniline } \\
(\mathrm{m} \mu \mathrm{moses} / \mathrm{mg} \text { prot. } / 30 \mathrm{~min})\end{array}$ & 6.16 & 12.39 & 5.17 & 7.91 & 19.4 & \pm 1.5 \\
\hline
\end{tabular}

a) Rats weighing 400 to $430 \mathrm{~g}$ were used.

c) 2,6-Dichloroptenol indophenol b) Mean \pm S.E. $(n=5)$, calculated from 5 animals. d) neotetrazclium

Table II shows enzymic activities of NADPH-linked microsomal electron transport system and content of cytochrome P-450 in three subjects. The enzyme activities and cytochrome P-450 could be detected in all of the three subjects. It is of interest that activity of NADPH-cytochrome $c$ reductase was lower than that of Darby's report? ${ }^{7)}$ but cytochrome p-450 content in both experiments were similar. In most cases of our experiments activities of NADPH-cytochrome $c$ reductase, NADPH-oxidase, NADPH-2,6-dichlorophenol indophenol diaphorase, NADPH-ferricyanide reductase and NADPH-neotetrazolium diaphorase in human liver microsomes were lower than those observed in normal male rats. There was no correlation between activities of microsomal electron transporting enzymes and activity of aniline hydroxylase, and moreover, activity of aniline hydroxylase was not always proportional to the amount of cytochrome P-450. 